\title{
Non-Small Cell Lung Cancer in Young Patients: An Analysis of Clinical, Pathologic and TNM Stage Characteristics Compared to the Elderly
}

This article was published in the following Dove Press journal: Risk Management and Healthcare Policy

Xin Jin

Xin Zhao

Xingsheng Liu

Ke Han

Gaojun Lu

Yi Zhang (D)

Thoracic Surgery Department, Xuanwu Hospital, Capital Medical University,

Beijing, People's Republic of China
Correspondence: Yi Zhang

Thoracic Surgery Department, Xuanwu Hospital, Capital Medical University,

Beijing, People's Republic of China

Tel +86-10-83922236

Email zhangyi@xwhosp.org
Purpose: To compare clinicopathologic factors including tumor-node-metastasis (TNM) stage between young and elderly patients with non-small cell lung cancer (NSCLC).

Methods: This retrospective study compared the following characteristics between 52 young patients with NSCLC ( $<50$ years of age) and 67 elderly patients with NSCLC (>60 years): duration of symptoms before medical consultation, smoking index, family history of cancer, Ki-67 index, and pTNM stage. A binary logistic regression analysis was used to identify factors predictive of greater stage NSCLC (stage III/IV compared to stage I/II) within each age group.

Results: The incidence of adenocarcinoma was higher in the young than in the elderly $(\mathrm{P}=0.006)$. Smoking index $(\mathrm{P}=0.002)$ and Ki-67 index $(\mathrm{P}<0.001)$ were lower in the young than in the elderly. In young patients with NSCLC, delayed treatment (greater duration from symptoms to medical consultation, $\mathrm{P}=0.050$ ) and active tumor proliferation (higher Ki-67 index, $\mathrm{P}=0.003$ ) were predictive of more advanced cancer stage (III/IV), with only symptom duration being predictive of stage III/IV NSCLC among elderly patients. Among young patients, cough $(\mathrm{P}=0.021)$ and chest congestion $(\mathrm{P}=0.040)$ were the most significant warning symptoms of advanced-stage NSCLC.

Conclusion: High tumor proliferation and delayed treatment are predictive of advanced NSCLC on presentation among young individuals. Early diagnosis by imaging, such as with the use of low dose computed tomography (LDCT), for young individuals with coughing and chest congestion over 1 month might be effectiveto improve prognosis and outcomes.

Keywords: NSCLC, young adult patients, symptom assessment, Ki67

\section{Introduction}

Lung cancer is the most common and lethal type of cancer worldwide, with a morbidity rate of $11.6 \%$ and a mortality rate of $18.4 \% .{ }^{1}$ Most new lung cancer cases and deaths occur in patients 60-70 years of age. ${ }^{2}$ However, the incidence rate of lung cancer among younger individuals is not insignificant at $5 \%-10 \%{ }^{3}$ and, therefore, should not be ignored. However, current research on non-small cell lung cancer (NSCLC) among younger individuals is insufficient. In part, the definition of "young" itself is controversial and confusing, with cutoff ages of 40 years, 4,5 45 years, 6,7 and 50 years ${ }^{8,9}$ having been used to define "young." Therefore, a unified age standard to guide research is lacking.

Moreover, tumorigenesis itself is a complicated process with numerous influential factors. The National Comprehensive Cancer Network (NCCN) has suggested 
that individuals with certain characteristics such as a smoking history, family history of lung cancer, and radiologic factors should be periodically examined for lung cancer prevention. ${ }^{10}$ Of note, some of these risk factors such as smoking and radiation may give rise to lung cancer due to years of exposure. As such, the contribution of these factors to NSCLC in young and elderly individuals needs to be evaluated beyond simply their "presence" or "absence." An objective standard for comparing clinicopathologic factors between young and elderly patients with NSCLC would be desirable in this regard.

Human factors influence disease progression and therefore need to be considered. Specifically, it is well recognized that some patients overlook early diseases symptoms and, thus, miss the opportunity for early diagnosis. Moreover, it is possible that a cancer with onset at a young age might reflect genetic susceptibility. These human risk factors can influence the tumor proliferation rate, playing an important role in oncogenesis and prognosis. $^{11,12}$ Therefore, the aim of this study was to compare clinicopathologic factors including tumor-nodemetastasis (TNM) stage between young and elderly patients with NSCLC.

\section{Patients and Methods}

\section{Patient Selection}

In this single-center retrospective study, patients eligible for our study group were those receiving surgical treatment for NSCLC in our department, between November 2013 (when electronic medical records were implemented at our hospital) and March 2019. To balance the sample size and subgroup difference, patients $<50$ years of age were classified as young patients, with the elderly comparison group comprising patients $>60$ years of age, in whom the incidence of NSCLC is the highest (as mentioned above). To eliminate the effects of confounding symptoms, we excluded patients with chronic respiratory and cardiovascular diseases such as chronic obstructive pulmonary disease (COPD), tuberculosis, coronary heart disease, or heart failure. Patients with incomplete records were also excluded.

Information of the following variables was extracted from patients' records in our hospital's electronic information system: sex; age at the time of diagnosis; duration of symptoms until medical consultation; smoking index (cigarettes smoked per day $\times$ years of tobacco use); family history of cancer; histologic type of tumor; and the Ki-67 index, described below. The pTNM stage was evaluated according to the 8th edition of the lung cancer staging classification system. ${ }^{13}$

\section{Statement of Ethics}

This study complied with the Declaration of Helsinki, conformed with the relevant regulations and was approved by ethics committee of Xuanwu Hospital, Capital Medical University. All patients provided informed consent for the surgical treatment and for the use of their medical information for research.

\section{Ki-67 Index Assessment}

Surgically resected tissue was made into slices and observed under 400-fold high-power field. Positive-nuclear cells were counted out of 100 cells in 10 randomly selected fields. Ki-67 index $=($ number of positive cells $/ 1000) \times 100 \%$.

\section{Statistical Analysis}

The Pearson's chi-squared test and Fisher's exact test were used to analyze patients' gender, symptoms, family history, histological type and TNM stage. The quantitative data were examined under independent-samples $t$-test (normal distribution) or Nonparametric test (abnormal distribution) in corresponding age subgroups. The binary logistic regression was used to evaluate meaningful clinicopathologic characteristics between stage I/II and stage III/IV patients. All statistical analyses were conducted in the SPSS 20.0 for Windows (SPSS Inc., Chicago, IL, USA). $\mathrm{P}<0.05$ was considered statistically significant.

\section{Results}

Within our study period, from November 2013 through March 2019, 1936 patients received surgical treatment for NSCLC. Of them, 119 met our exclusion criteria and were enrolled in our study: 52 in the young group and 67 in the elderly group. Patients' clinicopathologic characteristics are summarized in Table 1.

\section{A Comparison of Clinical and Pathological Characteristics in Young and Elderly Patients}

The young group included 52 patients, 26 males, with a mean age of $44.5 \pm 5.48$ years and a mean initial symptom duration of $3.23 \pm 6.95$ months. Of them, 13 were smokers (with a smoking index ranging 
Table I Clinical and Pathological Characters in Young Patients Comparing with the Elderly

\begin{tabular}{|c|c|c|c|c|}
\hline \multicolumn{2}{|l|}{ Variables } & $\begin{array}{l}\text { Young } \\
\text { Patients } \\
(n=52)\end{array}$ & $\begin{array}{l}\text { Elderly } \\
\text { Patients } \\
(n=67)\end{array}$ & $P$ value \\
\hline \multicolumn{2}{|c|}{$\begin{array}{l}\text { Gender (Male/Female, F\%) } \\
\text { Age/y (Min-Max, Mean } \pm \text { SD) }\end{array}$} & $\begin{array}{l}26 / 26,50.00 \% \\
25-50,44.5 \\
\pm 5.48\end{array}$ & $\begin{array}{l}4 I / 26,38.81 \% \\
60-78,68.0 \\
\pm 5.14\end{array}$ & 0.222 \\
\hline $\begin{array}{l}\text { Symptoms } \\
(\mathrm{n}, \%)\end{array}$ & $\begin{array}{l}\text { Cough } \\
\text { Hemosputum } \\
\text { Chest Pain } \\
\text { Chest } \\
\text { Congestion } \\
\text { Fever } \\
\text { Weight Loss } \\
\text { Others } \\
\text { Asymptomatic }\end{array}$ & $\begin{array}{l}22,42.31 \% \\
6,11.54 \% \\
9,17.31 \% \\
8,15.38 \% \\
3,5.77 \% \\
5,9.62 \% \\
3,5.77 \% \\
20,38.46 \%\end{array}$ & $\begin{array}{l}32,47.76 \% \\
12,17.91 \% \\
6,8.96 \% \\
9,13.43 \% \\
5,7.46 \% \\
5,7.46 \% \\
2,2.99 \% \\
26,38.80 \%\end{array}$ & - \\
\hline \multicolumn{2}{|c|}{$\begin{array}{l}\text { Symptom Duration/Mo (Mean } \\
\pm S D \text { ) }\end{array}$} & $3.23 \pm 6.95$ & $1.72 \pm 2.87$ & 0.145 \\
\hline \multicolumn{2}{|c|}{$\begin{array}{l}\text { Smoking Index (Min-Max, } \\
\text { Median, \%) }\end{array}$} & $\begin{array}{l}0-800,0 \\
25.00 \%\end{array}$ & $\begin{array}{l}0-2400,0 \\
49.25 \%\end{array}$ & 0.002 \\
\hline \multicolumn{2}{|c|}{ Family History(n,\%) } & $13,25.00 \%$ & $8,11.94 \%$ & 0.064 \\
\hline $\begin{array}{l}\text { Histological } \\
\text { Type }\end{array}$ & $\begin{array}{l}\operatorname{AIS}(n, \%) \\
\operatorname{ADC}(n, \%) \\
\operatorname{SCC}(n, \%) \\
\operatorname{ASC}(n, \%)\end{array}$ & $\begin{array}{l}8,15.38 \% \\
39,75.00 \% \\
4,7.69 \% \\
1,1.92 \%\end{array}$ & $\begin{array}{l}3,4.48 \% \\
44,65.67 \% \\
20,29.85 \% \\
0,0.00 \%\end{array}$ & 0.006 \\
\hline PTNM Stage & $\begin{array}{l}\text { O/I/II } \\
\text { III/IV }\end{array}$ & $\begin{array}{l}8 / 20 / 4,33 \\
14 / 5,19\end{array}$ & $\begin{array}{l}3 / 31 / 11,45 \\
20 / 2,22\end{array}$ & 0.673 \\
\hline \multicolumn{2}{|c|}{ Ki-67 Index (Mean $\pm S D)$} & $18.5 \% \pm 19.0 \%$ & $35.3 \% \pm 26.9 \%$ & $<0.001$ \\
\hline
\end{tabular}

between 2 and 800), 13 had a positive family history of malignant tumors, and 19 had a diagnosis of pTNM stage III or IV disease. The mean Ki-67 index was $18.5 \pm 19.0 \%$. Symptoms leading to a medical consultation included: coughing $(n=26)$; hemosputum $(n=6)$; chest pain $(n=9)$; chest congestion $(n=8)$; fever $(n=3)$; weight loss $(n=5)$; heart palpitations $(n=1)$; night sweat $(n=1)$; and one patient reported dizziness and headache, with this patient ultimately being diagnosed with brain metastases. The pathological classification of tumors among patients in this group was as follows: adenocarcinomas in situ (AIS), $\mathrm{n}=8$; adenocarcinomas (ADC), $\mathrm{n}=39$; squamous carcinoma ( $\mathrm{SCC}), \mathrm{n}=4$; and adenosquamous carcinoma (ASC), $n=1$.

The following characteristics were significantly different between the young and elderly groups: age $(\mathrm{P}<0.001)$, smoking index $(\mathrm{P}=0.002)$, histological tumor type $(\mathrm{P}=0.006)$, and $\mathrm{Ki}-67$ index $(\mathrm{P}<0.001)$, summarized in Table 1.

\section{Binary Logistic Regression Analysis of the Relation Between Risk Factors and PTNM Stage}

Within the young group, compared to patients with stage I/ II, those with stage III/IV had longer initial symptom duration before consultation, higher rate of smoking, and higher Ki-67 index and were predominantly male. The same factors were identified between patients with stage I/II and stage III/IV in the elderly group. On logistic regression analysis, symptom duration $(\mathrm{P}=0.05)$ and $\mathrm{Ki}-$ 67 index $(\mathrm{P}=0.003)$ were retained as predictive variables of stage III/IV cancer for the young group, indicating that delayed treatment and active tumor proliferation (higher Ki-67 index) are factors associated with advanced cancer stage. In the elderly group, only symptom duration was identified as a predictive factor $(\mathrm{P}=0.05)$. Results are shown in Tables 2 and 3.

\section{Symptom Differences Between Stages in Age Subgroups}

Presenting symptoms were also compared between patients with stage I/II and stage III/IV NSCLC within each age group (Table 4). Overall, the most common presenting symptoms among patients in our study group were cough, hemosputum, chest pain, chest congestion, fever, and weight loss. Of these, cough and chest congestion were more frequent among patients in stage III/IV than those in stage I/II (cough, 63.2\% versus 30.3\%, $\mathrm{P}=0.021$; chest congestion, $31.5 \%$ versus $6.1 \%, \mathrm{P}=0.040$ ) in the young group, which is hemosputum $(31.8 \%$ versus $11.1 \%, \mathrm{P}=0.038$ ) in elderly group.

\section{Discussion}

Cancer is often considered to be a "senile disease" because of its strong correlation with older age. With regard to lung cancer, this incidence rate of NSCLC among individuals $<50$ years of age is estimated at $5.6 \% .{ }^{14}$ The 2014 Japan Lung Cancer Registry Study ${ }^{15}$ reported a sharp increase in the incidence of lung cancer among patients $<50$ years of age. It is not uncommon for pulmonary lesions in young patients to be identified on LDCT, with patients seeking further medical consultation after identification. Although the predictive clinical characteristics of NSCLC in young individuals are still uncertain, specific pathological characteristics, smoking status, family history, and TNM stage are known factors that influence prognosis. Differences in risk factors between young and elderly patients might 
Table 2 Single Factor Analysis of the Relation Between Risk Factors and Staging

\begin{tabular}{|c|c|c|c|c|}
\hline & Variables & $0 / I / I I$ & III/IV & $P$ value \\
\hline \multirow[t]{6}{*}{ Young } & Gender (Male/Female, F\%) & $15 / 18,54.55 \%$ & $11 / 8,42.11 \%$ & 0.388 \\
\hline & Age/y (Mean $\pm S D)$ & $45.39 \pm 5.08$ & $42.84 \pm 5.89$ & 0.106 \\
\hline & Symptom Duration/Mo (Mean \pm SD) & $1.34 \pm 2.67$ & $6.52 \pm 10.29$ & 0.044 \\
\hline & Smoking Index (Min-Max, Median, \%) & $0-800,0,21.2 \%$ & $0-600,0,31.6 \%$ & 0.388 \\
\hline & Family History(n,\%) & $9,27.3 \%$ & $4,21.1 \%$ & 0.746 \\
\hline & Ki-67 Index (Mean $\pm S D)$ & $11.2 \% \pm 15.1 \%$ & $31.1 \% \pm 18.8 \%$ & $<0.001$ \\
\hline \multirow[t]{6}{*}{ Elderly } & Gender (Male/Female) & $26 / 19,42.22 \%$ & $15 / 7,31.82 \%$ & 0.412 \\
\hline & Age/y (Mean $\pm S D)$ & $68.0 \pm 5.18$ & $68.0 \pm 5.16$ & 0.973 \\
\hline & Symptom Duration/Mo (Mean \pm SD) & $1.22 \pm 2.15$ & $2.75 \pm 3.82$ & 0.091 \\
\hline & Smoking Index (Min-Max, Median, \%) & $0-2400,0,42.22 \%$ & $0-2400,500,63.64 \%$ & 0.276 \\
\hline & Family History(n,\%) & $6,13.30 \%$ & $2,9.10 \%$ & 1.000 \\
\hline & Ki-67 Index (Mean $\pm S D)$ & $31.8 \% \pm 22.7 \%$ & $42.5 \% \pm 24.0 \%$ & 0.125 \\
\hline
\end{tabular}

explain differences in the distribution of the types of NSCLC between young and elderly patients.

Among young patients, the incidence of $\mathrm{ADC}$ was higher than any other type of NSCLC (AIS, SCC, and ASC) and was specifically higher than the rate of ADC in the elderly group (Table $1,75.00 \%$ versus $65.67 \%$, respectively, $\mathrm{P}=0.006$ ). Previous studies have reported the high proportion of ADC among young patients with lung cancer, with the prevalence being higher in females than in males. ${ }^{5,9,16,17}$ We believe that this SCC-ADC shift may be a result of the accumulation of risk factors, one of which is tobacco use.
Smoking was more frequent among elderly than among young patients (Table $1, \mathrm{P}=0.002$ ). As a longer history of smoking would increase the accumulation of toxins over time, the risk of these toxins inducing gene mutations leading to lung cancer would also increase. Smoking has been associated with a higher specific risk for SCC (91\%), compared to ADC (82\%). ${ }^{18}$ We noted, from our findings, that the difference in the smoking index between patients with early- and late-stage NSCLC was not significantly different for both the young $(\mathrm{P}=0.388)$ and elderly $(\mathrm{P}=0.276)$ groups (Table 2). Therefore, smoking may have triggered the disease.

Table 3 Binary Logistic Regression Analysis of the Relation Between Risk Factors and Advanced Stage

\begin{tabular}{|l|l|l|l|l|l|l|}
\hline & Variables & B & S.E. & Wald & P value & OR (95\% CI) \\
\hline Young & Symptom Duration (M) & 0.172 & 0.088 & 3.825 & 0.05 & $1.187(1.000-1.410)$ \\
& Ki-67 Index & 7.311 & 2.485 & 8.652 & 0.003 & $1496.176(11.464-195,264.082)$ \\
\hline \multirow{2}{*}{ Elderly } & Symptom Duration (M) & 0.19 & 0.097 & 3.826 & 0.05 & $1.209(1.000-1.463)$ \\
& Ki-67 Index & 1.671 & 1.017 & 2.531 & 0.112 & $5.040(0.687-36.969)$ \\
\hline
\end{tabular}

Table 4 Symptoms Differences Between Staging

\begin{tabular}{|c|c|c|c|c|c|c|c|c|}
\hline & \multirow[t]{2}{*}{ Variables } & \multicolumn{6}{|l|}{ Symptom } & \multirow{2}{*}{$\begin{array}{l}\text { Initial Symptom } \\
\text { Duration/Mo }\end{array}$} \\
\hline & & Cough & Hemosputum* & $\begin{array}{l}\text { Chest } \\
\text { Pain* }\end{array}$ & $\begin{array}{l}\text { Chest } \\
\text { Congestion* }\end{array}$ & Fever* & $\begin{array}{l}\text { Weight } \\
\text { Loss* }\end{array}$ & \\
\hline Young & $\begin{array}{l}0+I+I I(n=33) \\
I I I+I V(n=19) \\
P \text { value }\end{array}$ & $\begin{array}{l}10,30.3 \% \\
12,63.2 \% \\
0.021\end{array}$ & $\begin{array}{l}3,9.1 \% \\
3,15.8 \% \\
0.656\end{array}$ & $\begin{array}{l}6,18.2 \% \\
3,15.8 \% \\
1\end{array}$ & $\begin{array}{l}2,6.1 \% \\
6,31.6 \% \\
0.040\end{array}$ & $\begin{array}{l}2,6.1 \% \\
I, 5.3 \% \\
I\end{array}$ & $\begin{array}{l}4,12.1 \% \\
I, 5.3 \% \\
0.641\end{array}$ & $\begin{array}{l}1.34 \pm 2.67 \\
6.52 \pm 10.29 \\
0.044\end{array}$ \\
\hline Elderly & $\begin{array}{l}0+I+I I(n=45) \\
I I I+I V(n=22) \\
P \text { value }\end{array}$ & $\begin{array}{l}20,44.4 \% \\
12,54.5 \% \\
0.437\end{array}$ & $\begin{array}{l}5,11.1 \% \\
7,31.8 \% \\
0.038\end{array}$ & $\begin{array}{l}4,8.9 \% \\
2,9.1 \% \\
\end{array}$ & $\begin{array}{l}5,11.1 \% \\
4,18.2 \% \\
0.461\end{array}$ & $\begin{array}{l}4,8.9 \% \\
\text { I, } 4.5 \% \\
\text { I }\end{array}$ & $\begin{array}{l}3,6.7 \% \\
2,9.1 \% \\
\end{array}$ & $\begin{array}{l}1.22 \pm 2.15 \\
2.75 \pm 3.82 \\
0.091\end{array}$ \\
\hline
\end{tabular}

Note: *Fisher's Exact Test. 
Various environmental factors other than smoking have been associated with lung cancer. Among these factors, second-hand smoking increases the risk for lung cancer among non-smokers by 1.31 (95\% confidence interval (CI) of the odds ratio, 1.17-1.45). ${ }^{19}$ Air pollution caused by PM2.5 or indoor radon ${ }^{20-22}$ and depression generated (identified in $40 \%$ of patients with advanced NSCLC) ${ }^{23}$ have also been associated with lung cancer. Considering the impact of these factors on the incidence of lung cancer, we propose that smoking status might be an "optional" condition to recommend advanced imaging such as thinslice computed tomography, rather than a "compulsory" condition. Further research is warranted to clarify this issue.

Family history was not a specific risk factor to NSCLC in the young group, with the presence of a family history of cancer not being different between the young and elderly groups (Table $1, \mathrm{P}=0.064$ ). We do note that a large sample study, including 5048 patients with lung cancer, reported a significant and marked increase in the risk for lung cancer for each additional lung cancer first-degree relative (relative risk, 2.57; 95\% CI, 2.39-2.76). ${ }^{24}$ Further research on this specific factor is warranted to improve screening algorithms for individuals at high risk for lung cancer.

The tumor proliferation characteristics also need to be considered. Tumorigenesis, as previously mentioned, is influenced by multiple factors and interactions. The high proliferation rate activated by these factors can explain why some patients, even without typical risk factors for lung cancer, are diagnosed with advanced NSCLC when first walking into a clinic. The Ki-67 index has been used in clinical practice to evaluate proliferative activity in many cancers, including lung cancer. ${ }^{25-27}$ The lower Ki-67 index for young than for elderly individuals in our study $(\mathrm{P}<0.001)$ would explain the higher proportion of early-stage diagnosis in the young group than in the elderly group and may be predictive of a better disease prognosis as previously reported. ${ }^{9,28}$ The difference in the Ki-67 index between patients with early-stage NSCLC than those with late-stage NSCLC within the young group (Table $2, \mathrm{P}<0.001$ ) may indicate that unique risk factors, other than smoking or family history, affect tumorigenesis among young patients.

Lastly, human factors must be considered. We note that the identification of non-symptomatic pulmonary nodules or masses has increased as a function of the increased use of LDCT (or other imaging technique) for screening of individuals deemed at high risk for lung cancer. Consequently, this has raised the diagnosis rate of lung cancer. Yet, delay in onset of symptoms and medical consultation for lung cancer remains a problem among young individuals who are more likely to ignore early symptoms such as cough or chest congestion. ${ }^{29,30}$ A delay in diagnosis results in more advanced stages of cancer at the time of presentation and a poor prognosis (Table 4, $\mathrm{P}=0.044$ ). In our research, we identified cough and chest congestion for $>1$ month as symptoms predictive of lung cancer among young patients. Therefore, young individuals presenting with these symptoms excluded the possibility of chronic diseases like COPD, coronary heart disease and asthma should be investigated for lung cancer.

Our research has several advantages over previous studies on this issue. Exposure to smoking, rather than simply a positive or negative history of smoking, should be considered in a screening algorithm. The Ki-67 index should also be included, based on the finding that the tumor proliferation rate itself plays an important role in the progression of NSCLC among young patients and, ultimately, prognosis. Early diagnosis is necessary to improve disease outcomes and survival among young patients with typical symptoms.

The limitations of our study also need to be considered. Foremost, the study has a retrospective design, which may have caused bias in the selection of the study group. This was a single-center study, and therefore, the study sample may not be comparable to that used in epidemiological studies from other regions, which limits comparison of findings. We did not evaluate the outcomes of the surgical treatment and did not perform a prognostic analysis due to the high rate of missing follow-up data.

\section{Conclusion}

This is one of the largest studies in China to analyze the relationship between clinical-pathological characteristics and TNM stage in young NSCLC patients after the 8th edition of the lung cancer staging classification system was published. It demonstrates that the high tumor proliferation and delayed treatment are predictive of advanced NSCLC on presentation among young individuals. Early diagnosis by imaging, such as with the use of LDCT, for young individuals with cough and chest congestion over 1 month might be effective for early diagnosis to improve prognosis and outcomes.

\section{Funding}

This study was supported in part by the grant from Beijing Hospitals Authority (XMLX201702). 


\section{Disclosure}

Xin Jin and Yi Zhang report grants from Beijing Hospitals Authority, outside the submitted work. The authors declare that they have no other potential conflicts of interests for this work.

\section{References}

1. Bray F, Ferlay J, Soerjomataram I, et al. Global cancer statistics 2018: GLOBOCAN estimates of incidence and mortality worldwide for 36 cancers in 185 countries. CA Cancer J Clin. 2018;68:394-424. doi:10.3322/caac. 21492

2. Chen W, Zheng R, Baade PD, et al. Cancer statistics in China, 2015. CA Cancer J Clin. 2016;66:115-132. doi:10.3322/caac.21338

3. Dell Amore A, Monteverde M, Martucci N, et al. Surgery for non-small cell lung cancer in younger patients: what are the differences? Heart Lung Circ. 2015;24:62-68. doi:10.1016/j. hlc.2014.07.054

4. Liam CK, Lim KH, Wong CMM. Lung cancer in patients younger than 40 years in a multiracial Asian country. Respirology. 2000;5:355-361. doi:10.1111/j.1440-1843.2000.00275.x

5. Skarin AT, Herbst RS, Leong TL, Bailey A, Sugarbaker D. Lung cancer in patients under age 40. Lung Cancer. 2001;32:255-264. doi:10.1016/S0169-5002(00)00233-6

6. Zhang J, Chen SF, Zhen Y, et al. Multicenter analysis of lung cancer patients younger than 45 years in Shanghai. Cancer. 2010;116:3656-3662. doi:10.1002/cncr.25100

7. Prasad R, Verma SK. Comparison between young and old patients with bronchogenic carcinoma. J Cancer Res Ther. 2009;5:31-35. doi:10.4103/0973-1482.44296

8. Radzikowska E, Roszkowski K, Głaz P. Lung cancer in patients under 50 years old. Lung Cancer. 2001;33:203-211. doi:10.1016/ s0169-5002(01)00199-4

9. Inoue M, Okumura M, Sawabata N, et al. Clinicopathological characteristics and surgical results of lung cancer patients aged up to 50 years: the Japanese Lung Cancer Registry study 2004. Lung Cancer. 2014;83:246-251. doi:10.1016/j.lungcan.2013.11.007

10. Wood DE, Kazerooni EA, Baum SL, et al. Lung cancer screening, version 3.2018, NCCN clinical practice guidelines in oncology. $J$ Natl Compr Canc Ne. 2018;16:412-441. doi:10.6004/jnccn. 2018.0020

11. Eric I, Petek EA, Kristek J, Koprivcic I, Babic M. Breast cancer in young women: pathologic and immunohistochemical features. Acta Clin Croat. 2018;57:497-502. doi:10.20471/acc.2018.57.03.13

12. Nowinska K, Ciesielska U, Piotrowska A, et al. MCM5 expression is associated with the grade of malignancy and Ki-67 antigen in LSCC. Anticancer Res. 2019;39:2325-2335. doi:10.21873/anticanres.13349

13. Detterbeck FC. The eighth edition TNM stage classification for lung cancer: what does it mean on main street? J Thorac Cardiovasc Surg. 2018;155:356-359. doi:10.1016/j.jtcvs.2017.08.138

14. Lara MS, Brunson A, Wun T, et al. Predictors of survival for younger patients less than 50 years of age with non-small cell lung cancer (NSCLC): a California cancer registry analysis. LUNG CANCER. 2014;85:264-269. doi:10.1016/j.lungcan.2014.04.007
15. Igata F, Uchino J, Fujita M, Iwasaki A, Watanabe K. Clinical features of lung cancer in Japanese patients aged under 50. Asian Pac J Cancer Prev. 2016;17:3377. doi:10.7314/apjcp.2016.17.4.2119

16. Lortet-Tieulent J, Soerjomataram I, Ferlay J, et al. International trends in lung cancer incidence by histological subtype: adenocarcinoma stabilizing in men but still increasing in women. Lung Cancer. 2014;84:13-22. doi:10.1016/j.lungcan.2014.01.009

17. Veness MJ, Delaney G, Berry M. Lung cancer in patients aged 50 years and younger: clinical characteristics, treatment details and outcome. Australas Radiol. 1999;43:328-333. doi:10.1046/j.14401673.1999.433666.x

18. Barbone F, Bovenzi M, Cavallieri F, Stanta G. Cigarette smoking and histologic type of lung cancer in men. Chest. 1997;112:1474-1479. doi:10.1378/chest.112.6.1474

19. Kim CH, Lee YA, Hung RJ, et al. Exposure to secondhand tobacco smoke and lung cancer by histological type: a pooled analysis of the international lung cancer consortium (ILCCO). Int $J$ Cancer. 2014;135:1918-1930. doi:10.1002/ijc.28835

20. Chen J. Canadian population risk of radon induced lung cancervariation range assessment based on various radon risk models. Radiat Prot Dosim. 2017;177:63-68. doi:10.1093/rpd/ncx133

21. Al-arydah MT. Population attributable risk associated with lung cancer induced by residential radon in Canada: sensitivity to relative risk model and radon probability density function choices. Sci Total Environ. 2017;596:331-341. doi:10.1016/j.scitotenv.2017.04.067

22. Lin X, Liao Y, Hao Y. The burden of cardio-cerebrovascular disease and lung cancer attributable to PM2.5 for 2009, Guangzhou: a retrospective population-based study. Int $J$ Environ Health Res. 2019;29:582-592. doi:10.1080/09603123.2018.1557605

23. Andersen BL, Valentine TR, Lo SB, et al. Newly diagnosed patients with advanced non-small cell lung cancer: a clinical description of those with moderate to severe depressive symptoms. LUNG CANCER. 2020;145:195-204.

24. Cannon-Albright LA, Carr SR, Akerley W. Population-based relative risks for lung cancer based on complete family history of lung cancer. $J$ Thorac Oncol. 2019;14(7):1184-1191. doi:10.1016/j.jtho.2019. 04.019

25. Jakobsen JN, Sørensen JB. Clinical impact of ki-67 labeling index in non-small cell lung cancer. Lung Cancer. 2013;79:1-7. doi:10.1016/j. lungcan.2012.10.008

26. Wen S, Zhou W, Li C, et al. Ki-67 as a prognostic marker in early-stage non-small cell lung cancer in Asian patients: a meta-analysis of published studies involving 32 studies. BMC Cancer. 2015;15. doi:10.1186/s12885-015-1524-2

27. Martin B, Paesmans M, Mascaux C, et al. Ki-67 expression and patients survival in lung cancer: systematic review of the literature with meta-analysis. Brit J Cancer. 2004;91:2018-2025. doi:10.1038/ sj.bjc. 6602233

28. Gomes R, Dabó H, Queiroga H, Hespanhol V. Non-small cell lung cancer in young patients - a retrospective analysis of 10 years in a tertiary university hospital. Revista Portuguesa De Pneumologia. 2016;22:125-126. doi:10.1016/j.rppnen.2015.10.001

29. Bourke W, Milstein D, Giura R, et al. Lung cancer in young adults. Chest. 1992;102:1723-1729. doi:10.1378/chest.102.6.1723

30. Bryant AS, Cerfolio RJ. Differences in outcomes between younger and older patients with non-small cell lung cancer. Ann Thorac Surg. 2008;85:1739. doi:10.1016/j.athoracsur.2008.01.031 


\section{Publish your work in this journal}

Risk Management and Healthcare Policy is an international, peerreviewed, open access journal focusing on all aspects of public health, policy, and preventative measures to promote good health and improve morbidity and mortality in the population. The journal welcomes submitted papers covering original research, basic science, clinical \& epidemiological studies, reviews and evaluations, guidelines, expert opinion and commentary, case reports and extended reports. The manuscript management system is completely online and includes a very quick and fair peer-review system, which is all easy to use. Visit http://www.dovepress.com/testimonials.php to read real quotes from published authors. 